\title{
FAKTOR SOSIAL DAN DEMOGRAFI YANG BERHUBUNGAN DENGAN PEKERJA LANSIA DI INDONESIA
}

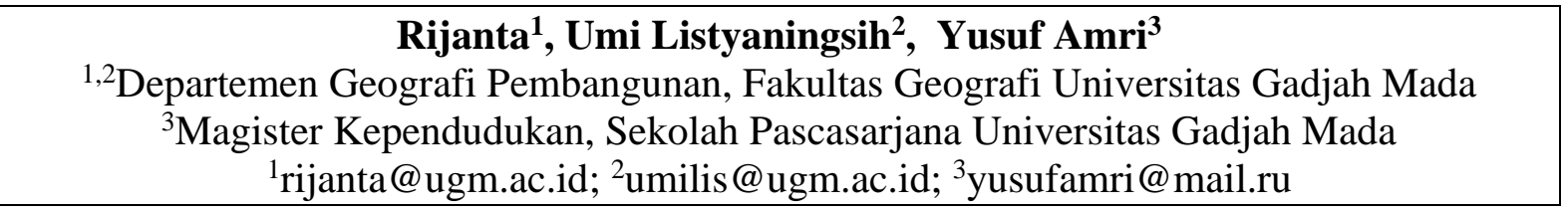

Diterima: Juni 2020; Disetujui: Desember 2020

Abstract. Indonesia's elderly worker increase each year and now is 50th in the world. Increase in the number of elderly people in Indonesia is an indicator of success of development in health sector. Marked by an increase in life expectancy. On the other hand, this is a social and economic burden on the state. We use 65+ years old as border age of elderly in this research. The objectives are to describe the social \& demographic characteristic of the elderly worker and to find the correlations among social \& demographic factors with working status of elderly worker in Indonesia. The methods are descriptive analysis (frequency and crosstab table) and inferential analysis of correlation (Chi Square test). Majority of elderly worker in Indonesia is women, married, head of household, 65-74 years old, occupied in informal sector, average of working time 34,23 hour per week, had health illness, no social security and debt. Chi square test results show that working status is moderately correlated with ages, sex, marital status, status in the household, and working hour. Then, social security is weak and another factor (education, health illness, debt, and occupation sector) is very weak.

Keyword: correlation, demographic factor, elderly worker, social factor, working status.

Abstraksi. Pekerja lansia di Indonesia meningkat setiap tahun dan masuk peringkat 50 besar di dunia. Peningkatan jumlah penduduk lanjut usia di Indonesia menjadi indikator keberhasilan pembangunan bidang kesehatan yang ditandai dengan peningkatan angka harapan hidup (AHH). Disisi lain hal ini menjadi beban negara baik secara sosial maupun ekonomi. Usia penduduk lansia pada penelitian ini adalah 65 tahun ke atas. Tujuan penelitian adalah mendeskripsikan karakteristik sosial \& demografi, dan menemukan faktor sosial \& demografi yang berhubungan dengan status kerja lansia di Indonesia. Metode yang digunakan yaitu analisis deskriptif (tabel silang dan tabel frekuensi) dan analisis inferensia korelasi (uji Chi Square). Pekerja lansia di Indonesia mayoritas adalah perempuan, kawin, kepala rumah tangga, umur 65-74 tahun, bekerja di sektor informal, rata-rata jam kerja 34,23 jam per minggu, memiliki keluhan kesehatan, pendidikan rendah, tidak memiliki jaminan sosial dan hutang. Menurut uji chi square, status kerja berhubungan sedang dengan umur, jenis kelamin, status perkawinan, hubungan dengan kepala rumah tangga, jam kerja. Kemudian jaminan sosial berhubungan lemah, dan faktor lainnya (pendidikan, keluhan kesehatan, hutang, dan sektor usaha) berhubungan sangat lemah.

Kata kunci: faktor demografi, faktor sosial, korelasi, pekerja lansia, status kerja.

\section{PENDAHULUAN}

Indonesia memiliki jumlah penduduk mencapai 267.663.435 juta jiwa dengan ratarata pertumbuhan penduduk mencapai $1,49 \%$ per tahun. Sebagai salah satu negara dengan jumlah penduduk terbanyak di dunia, Indonesia memiliki tantangan besar yaitu struktur umur penduduk mulai menua (population aging). Ada sekitar 23,4 juta jiwa penduduk lansia di Indonesia tahun 2017 atau sekitar 8,97\% dari total populasi. Jumlah ini akan terus meningkat setiap tahun dan diperkirakan akan menjadi sekitar $15 \%$ 
pada tahun 2035 (Badan Pusat Statistik, 2018).

Fenomena ini tidak hanya terjadi di Indonesia tetapi juga di beberapa negara di dunia. Secara global, sebanyak $12 \%$ penduduk dunia adalah lansia (lansia). Jumlah tersebut diprediksi akan meningkat menjadi dua kali lipat pada tahun 2050 (Pakulski, 2016). Meskipun faktanya fenomena population aging disetiap negara berbeda-beda karakteristiknya.

Secara umum, population aging adalah kondisi dimana persentase penduduk lansia di suatu wilayah mencapai lebih dari $10 \%$ akibat perubahan struktur umur penduduk. Diawali dengan penurunan angka kelahiran total secara bertahap kemudian seiring berjalannya waktu, terjadi pergeseran struktur umur. Penduduk kelompok umur produktif (15-64 tahun) akan bertambah, dan jumlah penduduk umur muda ( $<15$ tahun) akan berkurang karena fertilitas menurun. Ketika jumlah penduduk usia produktif lebih banyak daripada penduduk usia nonproduktif maka kondisi ini disebut Bonus Demografi (Heryanah, 2015). Kemudian penduduk usia non-produktif menjadi beban tanggungan secara ekonomi bagi penduduk usia produktif (Goldstein, 2009). Semakin banyak jumlah penduduk lansia maka beban ekonomi (Menon \& Melendez, 2009) dan beban sosial (Shrestha, 2000) akan semakin besar.

Bonus demografi di Indonesia berbedabeda di setiap provinsi tergantung dari bentuk piramida penduduknya. Bahkan ada provinsi yang tidak akan mengalami bonus demografi yaitu Sumatera Barat (Andriani, Pitoyo, \& Pangaribowo, 2018). Bonus demografi di Indonesia merupakan salah satu dampak jangka panjang dari keberhasilan Program Keluarga Berencana (KB) tahun 1980an. Program KB menyebabkan terjadinya penurunan angka kelahiran di Indonesia pada periode 19861994 dan ekonomi makro mulai tumbuh positif (Molyneaux \& Gertler, 2000).

Beberapa provinsi di Indonesia sudah melewati bonus demografi dan sebagian lainnya belum atau sedang mengalami. Ketika bonus demografi sudah terlewati maka struktur umur penduduk Indonesia akan mulai menua. Jumlah penduduk lansia akan terus bertambah sehingga membentuk piramida konstruktif. Pertambahan penduduk lansia dapat dipercepat dengan meningkatnya Angka Harapan Hidup (Niehof, 1995 ) sementara Angka Kelahiran Total (TFR) menurun.

Bertambahnya penduduk lansia di Indonesia belum dapat diimbangi dengan pemberian jaminan sosial secara merata. Jaminan sosial bagi lansia di Indonesia masih sangat terbatas. Umumnya hanya mereka yang pernah bekerja di sektor formal yang mendapatkan jaminan sosial (Cook \& Pincus, 2014). Akibatnya sebagian dari penduduk lansia tetap aktif bekerja untuk terus bertahan hidup (Affandi, 2009).

Persentase pekerja lansia di Indonesia terus mengalami peningkatan dari tahun ke tahun. Tahun 2010 ada sekitar 44,76\% pekerja lansia dan meningkat menjadi 47,92\% pada tahun 2017 (Badan Pusat Statistik, 2017). Partisipasi tenaga kerja lansia di negara berkembang memang cenderung lebih tinggi dibandingkan negara maju (Samorodov, 1999). Fenomena ini merupakan bentuk respon penduduk lansia terhadap kondisi ekonominya yang belum aman sehingga mereka tetap bekerja demi memenuhi kebutuhan hidup (Chen \& Powell, 2012).

Suplai tenaga kerja di suatu wilayah salah satunya ditentukan oleh faktor demografi. Proses demografi ada tiga yaitu kelahiran, kematian, dan migrasi. Proses demografi yang paling berpengaruh terhadap suplai 
tenaga kerja adalah kelahiran dan migrasi (Ivanov, 2009). Selain faktor demografi, faktor sosial juga berperan besar terhadap perubahan setiap kondisi ketenagakerjaan di suatu wilayah (Field, Uppal, \& LaRochelleCote, 2017). Kondisi ketenagakerjaan sensitif terhadap perubahan faktor sosial dan demografi seperti umur, jenis kelamin, pendidikan dan sebagainya (Hussain, Anwar, \& Huang, 2016).

Ada beberapa faktor sosial yang mempengaruhi status kerja lansia. Diantaranya adalah keluhan kesehatan (Kwon, Park, Lee, \& Cho, 2016); kepemilikan jaminan sosial, kepemilikan hutang, jumlah jam kerja, pendidikan (Adhikari, Soonthorndhada, \& Haseen, 2011) dan sektor usaha (Vodopivec \& Arunatilake, 2011).

Tujuan dari penelitian ini adalah Mendeskripsikan karakteristik sosial dan demografi pekerja lansia, memetakan distribusi spasial tenaga kerja lansia menurut provinsi, dan menganalisis hubungan antara faktor sosial dan demogafi dengan status kerja lansia di Indonesia.

\section{METODE PENELITIAN}

Penelitian ini menggunakan pendekatan kuantitatif (quantitative approach) yang terdiri dari deskriptif dan inferensia. Pendekatan kuantitatif dianalisis dengan dua cara yaitu analisis deskriptif dan analisis korelasi. Analisis deskriptif menjelaskan karakteristik sosial dan demografi pekerja lansia di Indonesia.

Analisis korelasi dengan uji Chi Square untuk mengetahui kekuatan hubungan antara faktor sosial dan demografi dengan status kerja lansia. Nilai Chi Square diperoleh dengan perhitungan menggunakan tabel kontingensi $2 \times 2$ sebab semua skala datanya nominal. Ada tidaknya hubungan variabel terikat dengan variabel bebas dilihat dari nilai signifikansi. Perhitungan nilai Chi Square dilakukan dengan menggunakan Software SPSS 20.

Rumus hitungnya sebagai berikut :

$C=\sqrt{\frac{x^{2}}{N+x^{2}}}$ dimana $x^{2}=\frac{\left(f_{0}-f_{h}\right)^{2}}{f_{h}}$

$\mathrm{C}=$ koefisien kontingensi

$\mathrm{N}=$ total sampel

$\mathrm{X}^{2}=$ nilai chi square yang diperoleh

Kemudian analisis kekuatan hubungan antara variabel bebas dengan variabel terikat dilihat dari koefisien Phi (karena tabel kontingensi 2x2). Interpretasi koefisien $P h i$ dengan tabel berikut:

Tabel 1.

Interpretasi Koefisien Phi \& Cramer's V

\begin{tabular}{cc}
\hline $\begin{array}{c}\text { Phi \& } \\
\text { Cramer's } V\end{array}$ & Kekuatan Hubungan \\
\hline $0.00-0.09$ & Sangat Lemah \\
$0.10-0.19$ & Lemah \\
$0.20-0.39$ & Sedang \\
$0.40-0.59$ & Kuat \\
$0.60-0.79$ & Sangat Kuat \\
$0.80-1.00$ & Sempurna \\
\hline \multicolumn{2}{c}{ Sumber : Pace (2012) }
\end{tabular}

Unit analisis penelitian ini adalah seluruh provinsi di Indonesia. Sumber data diperoleh dari Survei Sosial Ekonomi Nasional (SUSENAS) kor 2017 milik Badan Pusat Statistik. Variabel terikatnya adalah status kerja lansia dan variabel bebasnya terbagi dua kategori yaitu variabel sosial dan variabel demografi.

Variabel sosial terdiri dari keluhan kesehatan, kepemilikan jaminan sosial, jumlah jam kerja dalam seminggu, sektor usaha (formal/informal), dan kepemilikan hutang. Variabel demografi yang dianalisis yaitu jenis kelamin, umur, status 
perkawinan, pendidikan, dan hubungan dengan kepala rumah tangga.

\section{HASIL DAN PEMBAHASAN}

\section{Karakteristik Sosial dan Demografi Pekerja Lansia}

Karakteristik sosial dilihat dari variabel keluhan kesehatan, hutang, jaminan sosial, jam kerja, kedudukan pada pekerjaan utama. Karakteristik demografi dilihat dari variabel pendidikan, umur, status perkawinan, jenis kelamin, dan hubungan dengan kepala rumah tangga.

Mayoritas pekerja lansia di Indonesia memiliki keluhan kesehatan (54,1\%). Pekerja lansia perempuan cenderung lebih sehat dibanding laki-laki. Persentase pekerja lansia perempuan yang dengan keluhan kesehatan hanya $16,4 \%$, sedangkan laki-laki $(37,7 \%)$. Kondisi ini mirip di Thailand dimana ada lebih dari setengah penduduk lansia yang memiliki status kesehatan fisik relatif rendah (Loichinger \& Pothisiri, 2018).

Menurut Ogawa et al (2005) lansia yang memiliki keluhan kesehatan cenderung tidak bekerja. Lebih lanjut, Raymo et al., (2009) mengatakan bahwa keputusan lansia untuk bekerja atau tidak bekerja dipengaruhi oleh insentif atau jaminan sosial. Meskipun lansia ada keluhan kesehatan, mereka tetap akan bekerja jika tidak ada jaminan finansial untuk mereka baik berupa jaminan sosial dari negara atau bantuan keuangan dari keluarga.

Sebanyak 97,7\% pekerja lansia di Indonesia bekerja kurang dari 35 jam per minggu dan $2,3 \%$ bekerja penuh yaitu lebih dari 35 jam per minggu. Rata-rata jam kerja mereka mencapai 33,91 jam per minggu. Jam kerja lansia bervariasi mulai dari 1 jam hingga 40 jam per minggu. Lansia laki-laki $(1,4 \%)$ lebih banyak yang bekerja penuh daripada lansia perempuan $(0,9 \%)$. Secara umum pekerja lansia di Indonesia masih bekerja keras layaknya penduduk usia produktif lainnya.

Mayoritas pekerja lansia di Indonesia bebas hutang (83\%). Artinya mereka tetap bekerja di usia senja bukan karena tekanan hutang. Meskipun demikian, dari 17\% pekerja lansia yang memiliki beban hutang, ternyata didominasi oleh laki-laki $(12,3 \%$ : $4,7 \%$ ). Fakta yang menarik adalah pekerja lansia yang memiliki hutang lebih banyak ada di pedesaan $(10,9 \%)$ dibandingkan di perkotaan $(6,1 \%)$.

Hanya $7 \%$ pekerja lansia di Indonesia yang memiliki jaminan sosial dan laki-laki $(4,8 \%)$ mendominasi dengan persentase lebih besar dari perempuan $(2,1 \%)$. Pekerja lansia yang tidak memiliki jaminan sosial lebih banyak tinggal di pedesaan $(65,6 \%)$ dan sisanya tinggal di perkotaan.

Mayoritas lansia bekerja dengan berusaha sendiri $(38,5 \%)$ dan berusaha dibantu buruh tidak tetap/buruh tidak dibayar (32,5\%). Sementara itu yang paling sedikit adalah berusaha dibantu buruh tetap / buruh dibayar $(4,9 \%)$, pekerja bebas $(6,7 \%)$, dan buruh/ karyawan / pegawai $(7,9 \%)$. Ada lansia yang bekerja tidak dibayar sebesar 9,7\%.

Kelompok umur pekerja lansia di Indonesia dibagi menjadi 3 kelompok umur yaitu 65-74, 75-74, dan 85+ tahun. Distribusi pekerja lansia di Indonesia terbesar ada pada kelompok umur 65-74 tahun (81,8\%), kemudian 75-84 tahun $(16,4 \%)$ dan yang paling sedikit adalah $85+$ tahun $(1,8 \%)$. Semakin bertambah umur lansia maka semakin sedikit yang aktif bekerja. Ada 0,4\% lansia umur di atas 90 tahun yang masih aktif bekerja. Sebagian besar dari mereka tinggal di pedesaan, bekerja di sektor informal dengan jam kerja kurang dari 35 jam per minggu.

Berikutnya adalah variabel jenis kelamin. Jenis kelamin menjadi variabel yang paling 
banyak digunakan dalam penelitian tentang ketenagakerjaan (Abdulloev, Gang, \& Yun, 2014). Meskipun penduduk lansia di Indonesia tahun 2017 didominasi oleh perempuan $(54,2 \%)$, namun untuk lansia yang bekerja ternyata didominasi oleh lakilaki $(69,2 \%)$. Secara teori memang perempuan cenderung hidup lebih lama dari laki-laki (Eskes \& Haanen, 2007). Hal ini dibuktikan dengan Angka Harapan Hidup perempuan di Indonesia tahun 2017 mencapai 73,06 tahun dan laki-laki hanya 69,16 tahun.

Sebagai negara berkembang, pekerja lansia di Indonesia masih memiliki tingkat pendidikan yang relatif rendah. Sebagian besar pekerja lansia berpendidikan SD ke bawah $(83,4 \%)$. yang tamat SMP dan sederajat ada $8 \%$, tamat SMA dan sederajat ada $6,6 \%$, dan tamat perguruan tinggi ada $2,1 \%$. Tingkat pendidikan pekerja lansia perempuan lebih rendah dibanding laki-laki. Secara teori hal ini disebabkan adanya kesenjangan yang nyata akses pendidikan antara laki-laki dan perempuan di masa lalu (Kaneda \& Zimmer, 2007). Selain itu tingkat pendidikan pekerja lansia di pedesaan lebih rendah daripada di perkotaan. Perbedaan tingkat pendidikan antara pedesaan dan perkotaan sejalan dengan perbedaan karakteristik sosial \& ekonomi (Kadar, Francis, \& Sellick, 2013).

Menurut Sheyki (2016) status perkawinan lansia memiliki hubungan dengan kondisi sosial dan ekonomi. Hidup bersama pasangan menjadikan lansia lebih stabil secara psikologis, terutama lansia perempuan (Rosenfield \& Mouzin, 2013). Pada tahun 2017 sebagian besar pekerja lansia di Indonesia berstatus kawin $(70,4 \%)$. Lalu cerai mati $26,5 \%$, cerai hidup $1,9 \%$, dan belum kawin 1,1\%. Pekerja lansia laki-laki lebih banyak yang berstatus kawin atau masih hidup bersama pasangan (59\%). Sebaliknya, mayoritas pekerja lansia perempuan berstatus cerai mati $(17,8 \%)$.

Variabel demografi yang terakhir adalah hubungan dengan kepala rumah tangga atau status dalam rumah tangga. Mayoritas pekerja lansia berstatus sebagai kepala rumah tangga (81,3\%). Dari 81,3\% tersebut, $65,3 \%$ diantaranya adalah laki-laki dan $16 \%$ lainnya perempuan. Secara kultur, kepala rumah tangga dipegang oleh laki-laki. Perempuan baru menjadi kepala rumah tangga ketika sudah tidak memiliki pasangan baik cerai mati, cerai hidup, atau belum pernah menikah.

Tabel 2.

Hasil Uji Chi Square Antara Faktor Sosial dan Demografi dengan Status Kerja Lanjut Usia di Indonesia

\begin{tabular}{llllll}
\hline $\begin{array}{c}\text { Chi Square } \\
\text { (Test of Independence })\end{array}$ & \multicolumn{2}{c}{ Alfa $=\mathbf{0 , 0 5}$} & \multicolumn{2}{c}{ Kekuatan Hubungan } \\
No & Variabel X & $\begin{array}{c}\text { Asymp. Sig. } \\
(\mathbf{2} \text { sided })\end{array}$ & Keterangan & $\begin{array}{c}\text { Koefisien } \\
\boldsymbol{P h i}\end{array}$ & Keterangan \\
\hline Faktor Sosial & 0,000 & Ada Hubungan & $-0,079$ & Sangat Lemah \\
1 & Keluhan Kesehatan & 0,000 & Ada Hubungan & $-0,143$ & Lemah \\
2 & Jaminan Sosial & 0,000 & Ada Hubungan & 0,267 & Sedang \\
3 & Jumlah Jam Kerja & 0,000 & Ada Hubungan & $-0,015$ & Sangat Lemah \\
4 & Kepemilikan Hutang & 0,000 & Ada Hubungan & $-0,022$ & Sangat Lemah \\
5 & Sektor Formal / & 0,000 & & & \\
\hline
\end{tabular}




\begin{tabular}{|c|c|c|c|c|c|}
\hline \multicolumn{2}{|c|}{$\begin{array}{c}\text { Chi Square } \\
\text { (Test of Independence) }\end{array}$} & \multicolumn{2}{|c|}{ Alfa $=0,05$} & \multicolumn{2}{|c|}{ Kekuatan Hubungan } \\
\hline No & Variabel X & $\begin{array}{c}\text { Asymp. Sig. } \\
(2 \text { sided })\end{array}$ & Keterangan & $\begin{array}{c}\text { Koefisien } \\
\text { Phi }\end{array}$ & Keterangan \\
\hline \multicolumn{6}{|c|}{ Faktor Demografi } \\
\hline 6 & Umur & 0,000 & Ada Hubungan & $-0,215$ & Sedang \\
\hline 7 & Jenis Kelamin & 0,000 & Ada Hubungan & 0,325 & Sedang \\
\hline 8 & $\begin{array}{l}\text { Hubungan dengan } \\
\text { Kepala Rumah Tangga }\end{array}$ & 0,000 & Ada Hubungan & 0,329 & Sedang \\
\hline 9 & Status Perkawinan & 0,001 & Ada Hubungan & 0,273 & Sedang \\
\hline 10 & Pendidikan & 0,000 & Ada Hubungan & 0,024 & Sangat Lemah \\
\hline
\end{tabular}

Catatan : alfa $=0,05$; Chi Square dengan tabel kontingensi $2 \times 2$

Sumber : diolah dari SUSENAS kor 2017

Hubungan Antara Faktor Sosial dan Demografi dengan Status Kerja Lansia

Hasil uji statistik menunjukkan ada hubungan antara status kerja lansia dengan faktor sosial dan demografi. Walaupun demikian, terdapat variasi kekuatan hubungan antara status kerja lansia (variabel terikat) dengan faktor sosial dan demografi (variabel bebas) mulai dari hubungan yang lemah, sedang, kuat, dan sangat kuat.

Keluhan kesehatan memiliki nilai sig. $0,000<0,05$ dan koefisien phi -0,079. Artinya keluhan kesehatan memiliki hubungan yang sangat lemah dengan status kerja lansia di Indonesia tahun 2017. Secara teori keluhan kesehatan berhubungan kuat dengan status kerja, sedangkan temuan ini berhubungan sangat lemah. Kondisi kesehatan berpengaruh terhadap aktivitas produktif lansia (Oshio \& Shimizutani, 2019). Pada beberapa kasus, ada kecenderungan pekerja akan pensiun dini apabila menderita suatu penyakit (Aísa, Pueyo, \& Sanso, 2012).

Begitu juga dengan sektor usaha (formal/informal) dan kepemilikan hutang yang memiliki hubungan sangat lemah. Sektor usaha (formal/informal) memiliki nilai sig.0,000 $<0,05$ dan koefisien phi 0,015. Kepemilikan hutang memiliki sig.
$0,000<0,05$ dan koefisien phi -0,022. Pekerja lansia di Indonesia tidak berasosiasi dengan sektor usaha baik formal maupun informal dan kepemilikan hutang. Sebagai negara berkembang, pekerja lansia Indonesia cenderung banyak bekerja di sektor informal sebagai pilihan yang paling realistis.

Kepemilikan hutang juga tidak menjadi alasan lansia Indonesia tetap bekerja dan ini sejalan dengan temuan Belkar et al., (2007) bahwa kepemilikan hutang tidak berhubungan secara langsung dengan status kerja. Namun ada kecenderungan bahwa rumah tangga lansia yang memiliki hutang dalam jumlah besar akan cepat kembali mencari pekerjaan (Bednarzik, Kern, \& Hisnanick, 2017).

Jaminan sosial berhubungan lemah dengan status kerja lansia (sig.0,000<0,05 \& koefisien phi -0,143). Artinya jaminan sosial bukan faktor besar bagi lansia untuk bekerja. Sejalan dengan penelitian Febriani (2012) bahwa jaminan sosial tidak menjadi faktor penentu penduduk lansia di Indonesia untuk kembali bekerja. Meskipun Larsen \& Pedersen (2013) menyatakan bahwa jika negara memiliki sistem jaminan sosial yang baik, maka jumlah pekerja lansia akan turun dengan sendirinya. 
Sementara itu, jam kerja menjadi satusatunya faktor sosial dalam penelitian ini yang berhubungan sedang (moderate) dengan status kerja lansia (sig. $0,000<0,05 \&$ koefisien phi 0,267). Pekerja lansia Indonesia bekerja memiliki jam kerja per minggu lebih sedikit dibanding pekerja umur produktif. Mayoritas pekerja lansia bekerja kurang dari 35 jam per minggu. Hubungan status kerja lansia dengan jumlah jam kerja dikontrol oleh faktor kesehatan (Snyder \& Evans, 2006), pendidikan (Aliaj, et al., (2016) dan jenis pekerjaan (Rehkopf, Adler, \& Rowe, 2017).

Faktor demografi yang berhubungan sedang (moderate dengan status kerja lansia yaitu jenis kelamin (sig.0,000<0,05 \& koefisien phi 0,325), hubungan dengan kepala rumah tangga (sig.0,000<0,05 \& koefisien phi 0,0329), dan status perkawinan (sig.0,001<0,05 \& koefisien phi 0,273). Hal ini sejalan dengan teori bahwa di negara berkembang status kerja lansia berhubungan cukup kuat dengan jenis kelamin dan lansia laki-laki lebih dominan di pasar kerja dibanding perempuan (Vodopivec \& Arunatilake, 2011).

Lansia laki-laki juga cenderung lebih banyak yang berstatus sebagai kepala rumah tangga sehingga mereka akan tetap bekerja untuk menafkahi anggota keluarga. Status lansia sebagai kepala rumah tangga dikontrol oleh faktor umur dan kesehatan. Semakin bertambah umur dan semakin lemah kondisi kesehatan maka semakin kecil kesempatan untuk menyandang kepala rumah tangga (Rahman, 1999).

Faktor umur berhubungan sedang (moderate) dengan status kerja lansia di Indonesia (sig.0,000<0,05 \& koefisien phi 0,215). Semakin bertambah umur lansia maka semakin kecil peluang untuk kembali bekerja sebab fisiknya semakin melemah. Faktor umur secara teori berhubungan kuat atau berpengaruh terhadap keterlibatan penduduk lansia dalam aktivitas ekonomi produktif (Büsch, Dittrich, \& Lieberum, 2012).

Sementara itu, faktor pendidikan justru berhubungan sangat lemah dengan status kerja (sig.0,000<0,05 \& koefisien phi 0,024) meskipun ada penelitian yang menyatakan bahwa pendidikan berhubungan kuat (Larsen \& Pedersen, 2013) dan semakin tinggi pendidikan lansia maka peluang untuk kembali bekerja akan semakin besar (Gendell , 2008). Sebaliknya, menurut Konle-Seidl (2017) peran faktor pendidikan lebih berpengaruh terhadap keterampilan dan kemampuan lansia dalam bekerja daripada status kerjanya. Pada penelitian ini, pendidikan adalah faktor yang berhubungan lemah dengan status kerja lansia di Indonesia.

Di negara berkembang seperti Indonesia faktor pendidikan tidak berhubungan kuat dengan status kerja lanjut usia. Keterlibatan penduduk lanjut usia di pasar kerja lebih banyak disebabkan oleh dua faktor utama yaitu ekonomi dan kesehatan. Ketika lanjut usia dalam kondisi rentan secara finansial dan kesehatannya cukup bagus maka lanjut usia cenderung akan tetap bekerja (Samorodov, 1999). Saat akan masuk ke pasar kerja, penduduk lanjut usia akan melakukan pekerjaan yang ringan atau mengikuti pelatihan kerja untuk meningkatkan kemampuan (Horn, Krepcio, \& Heidkamp, 2015).

\section{SIMPULAN}

Terdapat variasi hubungan antara faktor sosial dan demografi dengan status kerja lansia di Indonesia tahun 2017. Secara umum faktor demografi memiliki hubungan lebih kuat dengan status kerja lansia dibandingkan faktor sosial. Ini artinya keterlibatan lansia di pasar kerja lebih 
banyak berkaitan dengan aspek demografi lansia daripada aspek sosial. Penelitian ini belum dapat menjelaskan seberapa jauh pengaruh faktor demografi terhadap status kerja lansia di Indonesia.

Secara umum faktor yang berhubungan sedang (moderate) dengan status kerja lansia adalah jam kerja $(\phi: 0,267)$; umur $(\phi:-$ $0.215)$; jenis kelamin $(\phi: 0,325)$; hubungan dengan kepala rumah tangga $(\phi: 0,329)$, dan status perkawinan $(\phi: 0,273)$. Jaminan sosial berhubungan sedang $(\phi:-0,143)$, dan lainnya yaitu keluhan kesehatan $(\phi:-0,079)$; hutang ( $\phi:-0,015)$; sektor usaha $(\phi:-0,022)$; dan pendidikan $(\phi: 0,024)$ berhubungan lemah dengan status kerja lansia di Indonesia.

Salah satu temuan yang menarik adalah faktor pendidikan justru berhubungan sangat lemah dengan status kerja lansia. Hal ini bertentangan dengan beberapa penelitian terdahulu dimana pendidikan berhubungan kuat dengan status kerja lansia. Sebagian lain justru pendidikan sampai berpengaruh terhadap status kerja lansia. Penelitian ini belum mampu menjelaskan mengapa pendidikan berhubungan lemah dengan status kerja lansia di Indonesia.

Sebagai negara sedang berkembang, mayoritas pekerja lansia di Indonesia tahun 2017 secara individual memiliki karakteristik sosial yaitu cenderung memiliki keluhan kesehatan, tidak memiliki jaminan sosial, dan tidak memiliki beban hutang. Pekerja lansia lebih banyak yang bekerja di sektor informal sebagaimana umumnya pekerja lansia di negara sedang berkembang. Jumlah jam kerja per minggu antara pekerja lansia laki-laki dan perempuan hampir sama namun laki-laki bekerja sedikit lebih lama.

Kemudian menurut karakteristik demografi, pekerja lansia di Indonesia lebih didominasi oleh laki-laki daripada perempuan. Sebagian besar berada pada kelompok umur 65-74 tahun. Semakin bertambah umur lansia semakin kecil kesempatan untuk tetap bekerja. Pekerja lansia masih banyak yang berstatus kawin, dan menjadi kepala rumah tangga. Kemudian tingkat pendidikan pekerja lanjut usia di Indonesia relatif masih rendah yaitu SD ke bawah.

\section{DAFTAR PUSTAKA}

Konle-Seidl, R. (2017). Retention and re-integration of older workers into the labour market: What works? IAB-Discussion Paper, No. 17/2017. Nürnberg: Institut für Arbeitsmarkt- und Berufsforschung (IAB).

Abdulloev, I., Gang, I. N., \& Yun, M.-S. (2014). Migration, Education and the Gender Gap in Labour Force Participation. IZA Discussion Paper No. 8226 May 2014, 1-36.

Adhikari, R., Soonthorndhada, K., \& Haseen, F. (2011). Labor Force Participation in Later Life: Evidence from a Cross-sectional Study in Thailand. BMC Geriatrics, Volume 11, No 15, 1-8.

Affandi, M. (2009). Faktor - Faktor Yang Mempengaruhi Penduduk Lanjut Usia Memilih Untuk Bekerja. Journal of Indonesian Applied Economics, Vol 3 No 2 : 99-110.

Aísa, R., Pueyo, F., \& Sanso, M. (2012). Life expectancy and labor supply of the elderly. Journal of Population Economics, Volume 25, No. 2 , 545-568.

Akoglu, H. (2018). User's Guide to Correlation Coefficients. . Turk J Emerg Med. Volume 18 No 3, 91-93. 
Aliaj, A., Flawinne, X., Jousten, A., Perelman, S., \& Shi, L. (2016). Old-age Employment and Hours of Work Trend : Empirical Analysis for Four European Countries. IZA Journal of Europena Labor Studies, Volume 5 No 16, 1-22.

Andriani, D. S., Pitoyo, A. J., \& Pangaribowo, E. H. (2018). Ketidaktercapaian Bonus Demografi : Pembelajaran Dari Sumatera Barat. Populasi. Volume 26 No 1, 1-15.

Assmann, F. (2016). Spatial Aspects of the Labor Market - Disertation. Bavaria, Germany: Universitat Regensburg.

Austad, S. N. (2006). Why Women Live Longer Than Men : Sex Differences in Longevity. Gender Medicine, Volume 3, No. 2, 79 - 92.

Badan Pusat Statistik. (2015). Proyeksi Penduduk Kabupaten / Kota Provinsi Kalimantan Timur. Jakarta: Badan Pusat Statistik.

Badan Pusat Statistik. (2017). Statistik Penduduk Usia Lanjut 2017. Jakarta: Badan Pusat Statistik.

Badan Pusat Statistik. (2018). Proyeksi Penduduk Indonesia 2015-2045. Jakarta: Badan Pusat Statistik.

Bednarzik, R. W., Kern, A., \& Hisnanick, J. J. (2017). Displacement and Debt: The Role of Debt in Returning to Work in the Period Following the Great Recession - IZA Discussion Papers, No. 10764. Bonn: Institute of Labor Economics (IZA),.

Belkar, R., Cockerell, L., \& Edwards, R. (2007). Labour Force Participation and Household Debt. Sydney: Economic Research Department of Reserve Bank of Australia.

Büsch, V., Dittrich, D., \& Lieberum, U. (2012). Determinants of Work Motivation and Work Ability among Older Workers and Implications for the Desire for Continued Employment. Comparative Population Studies - Zeitschrift für Bevölkerungswissenschaft, Volume 35, No 4 , 931-958.

Chen, S., \& Powell, J. L. (2012). Aging in China : Implications to Social Policy of a Changing Economic State. New York: Springer.

Cook, S., \& Pincus, J. (2014). Poverty, Inequality and Social Protection in Southeast Asia: An Introduction. Journal of Southeast Asian Economies, Vol. 31, No. 1, Policy Focus: Building Social Protection Systems in Southeast Asia (April 2014), 1-17.

Eskes, T., \& Haanen, C. (2007). Why do Women Live Longer Than Men? European Journal of Obstetrics \& Gynecology and Reproductive Biology Volume 133 (2007) 126-133, 126-133.

Febriani, R. E. (2012). Jaminan Sosial dan Penawaran Tenaga Kerja Lanjut Usia. Ecosains - Jurnal Ilmiah Ekonomi dan Pembangunan, Volume 1, No 2, 191-208.

Field, A., Uppal, S., \& LaRochelle-Cote, S. (2017). The Impact of Aging on Labour Market Participation Rates. Statistics Canada, 1-10.

Gendell , M. (2008). Older Workers: Increasing Their Labor Force Participation And Hours of Work. Mon Labor Rev Volume 131 No 1, 41-54.

Goldstein, J. (2009). How Population Age. Dalam P. Uhlenberg, International Handbook of Population Aging (hal. 7). Texas: University of North Carolina.

Heryanah. (2015). Ageing Population Dan Bonus Demografi Kedua Di Indonesia. Populasi. Volume 23 No 2 , 1-16. 
Horn, C. V., Krepcio, K., \& Heidkamp, M. (2015). Improving Education and Training For Older Workers. New Jersey: John J. Heldrich Center for Workforce Development Rutgers, The State University of New Jersey.

Hussain, M., Anwar, S., \& Huang, S. (2016). Socioeconomic and Demographic Factors Affecting Labour Force Participation in Pakistan. Journal of Sustainable Development Vol. 9 No. 4, 70-79.

Ivanov, S. (2009). Demographic and economic factors of labour supply: Long-term projections and policy options for France, Germany, Italy and the United Kingdom. Vienna Yearbook of Population Research, Vol. 7 , 83-122.

Kadar, K. S., Francis, K., \& Sellick, K. (2013). Ageing in Indonesia - Health Status and Challenges For the Future. Ageing International (2013), Volume 38, :261-270.

Kaneda, T., \& Zimmer, Z. (2007). Education, Gender, and Functional Transitions Among Indonesian Elderly. Journal of Cross Cult Gerontology, Volume 22, 303-322.

Kingma, N. C. (1991). Natural Hazard : Geomorphological Aspect of Floodhazard. The Netherland: ITC.

Kwon, K., Park, J. B., Lee, K.-J., \& Cho, Y.-S. (2016). Association between employment status and self-rated health: Korean working conditions survey. Annals of Occupational and Environmental Medicine Volume 28 No.43, 1-7.

Larsen, M., \& Pedersen, P. J. (2013). To Work, To Retire - Or Both? Labor Market Activity After 60. IZA Journal of $f$ European Labor Studies, Volume 2 No 21, 1-20.

Larsen, M., \& Pedersen, P. J. (2017). Labour force activity after 65: what explain recent trends in Denmark, Germany and Sweden? Journal of Labour Market Res, 15-27.

Loichinger, E., \& Pothisiri, W. (2018). Health prospects of older persons in Thailand: the role of education. Asian Population Studies, Volume 14, No 3, 310-329.

Menon, J., \& Melendez, A. C. (2009). Ageing in Asia : Trends, Impacts and Responses. ASEAN Economic Bulletin Vol. 26 No. 3, 293-305.

Molyneaux, J. W., \& Gertler, P. J. (2000). The Impact of Targeted Family Planning Programs in Indonesia. Population and Development Review. Vol. 26, Supplement : Population and Economic Change in East Asia, 61-85.

Niehof, A. (1995). Ageing and the Elderly in Indonesia : Identifying Key Issues. Bijdragen Tot De Taal-, Land- En Voolkenkunde, Vol 151 (3) : 422-437.

Ogawa, N., Lee, S.-H., \& Matsukura, R. (2005). Health and Its Impact on Work and Dependency Among the Elderly in Japan. Asian Population Studies Volume 1, No. 1 , 121-145.

Oshio, T., \& Shimizutani, S. (2019). Health capacity to work and its long-term trend among the Japanese elderly. Journal of the Japanese and International Economies, Volume 51 (March 2019), 76-86.

Pace, L. (2012). Beginning R: An Introduction to Statistical Programming. New York: APRESS.

Pakulski, J. (2016). Facing the challenges of an ageing society. Dalam H. Kendig, P. McDonald, \& J. Piggott, Population Ageing and Australia's Future (hal. 111-134). Australia: ANU Press. 
Rahman, M. O. (1999). Age and Gender Variation in the Impact of Household Structure on Elderly Mortality. International Journal of Epidemiology Volume 28, 485-491.

Rajaguguk, W., \& Samosir, O. B. (2015). Fakta dan Prospek Pemanfaatan Jendela Kesempatan dan Bonus Demografis : Studi Banding di Sulawesi Utara dan Nusa Tenggara Timur. Jakarta: Kerjasama UKI - BKKBN .

Raymo, J. M., Liang, J., Kobayashi, E., Sugihara, Y., \& Fukaya, T. (2009). Work, Health, and Family at Older Ages in Japan. Res Aging Volume 32 No 2, 180-206.

Rehkopf, D. H., Adler, N. E., \& Rowe, J. W. (2017). The impact of health and education on future labour force participation among individuals aged 55-74 in the United States of America: the MacArthur Foundation Research Network on an Aging Society. Ageing \& Society Voume 37, 1313-1337.

Rosenfield, S., \& Mouzin, D. (2013). Gender and mental health. Dalam C. S. Aneshnsel, J. C. Phelan, \& A. Bierman, Handbook of Sociology of Mental Mealth. Second Edition (hal. 277-298). New York: Kluwer.

Samorodov, A. (1999). Ageing and Labour Markets for Older Workers. Geneva: International Labour Office Geneva Swiss.

Sheykhi, M. T. (2016). State of widowhood in Iran: Challenges of ageing spouses. International Journal on Ageing in Developing Countries, Volume 1 No 1, 54 - 67.

Shrestha, L. B. (2000). Population Eging in Developing Countries. Health Affairs Vol 19 No 3, 204-212.

Snyder, S. E., \& Evans, W. N. (2006). The effect of income on mortality: evidence from the Social Security Notch. The Review of Economics and Statistics, Volume 88 No 3, 482495.

Vodopivec, M., \& Arunatilake, N. (2011). Population Aging and Labour Market Participation of Older Worker in Sri Lanka. Population Ageing Vol 4 , 141-163. 